Rafał KARAŚ

WSB University (Akademia WSB)

\title{
THE IMPACT OF TECHNOLOGICAL CHANGES OF PVC LIGHT PARTITIONS AND GLAZING ON THE RISK CONNECTED WITH THE ORGANIZATION OF INTERNATIONAL TRANSPORT \\ Wpływ zmian technologicznych lekkich przegród i przeszkleń PVC na ponoszone ryzyko w organizacji transportu międzynarodowego
}

\begin{abstract}
The Author of the article proves that in practice the suitable result concerning the balanced development and the effective use of resources should be controlled simultaneously. The setting of the parameters of thermal isolation for constructional products such as light partitions and glazing (windows and doors) with respect to technological development of products is not enough. Production, the product and its transport makes the whole arrangement of processes that influence the entirety resulting from ecology, transport and the effective use of resources. The only way to meet the demands of the strategy described in the EU documents is to implement such product design that assumes for example the optimal transport possibilities.
\end{abstract}

Keywords: transport, technology, production, PVC, thermal isolation coefficient

Streszczenie: Autor artykułu wykazuje, że w praktyce odpowiednim efektem dotyczacym zrównoważonego rozwoju $i$ efektywnego wykorzystania zasobów należy zarządzać kompleksowo. Ustalenie parametrów izolacji termicznej dla produktów budowlanych, jakimi sa np. lekkie przegrody i przeszklenia (okna i drzwi) $w$ odniesieniu do rozwoju technologicznego produktów nie wystarczy. Produkcja, produkt i jego transport to całe zastawienie procesów, które wpływają na całokształt zwiąany z ekologia, transportem oraz efektywnym wykorzystaniem zasobów. Tylko odpowiednie projektowanie produktów, które przewiduje np. optymalne możliwości transportu moga przynieść wymierne efekty zwiąane ze strategia opisana $w$ dokumentach Unii Europejskiej.

Słowa kluczowe: transport, technologia, produkcja, PVC, współczynnik izolacji termicznej 


\section{Introduction}

One of the prior activities of the European Union is to improve the quality of the natural environment and effective use of resources. Within this scope the European Union focused on the implementation of the so called 'balanced development'. This rule applies to the materials used in technological processes, product impact on natural environment throughout the whole period up to their utilization. In the branch of building material production the strategic goal is to limit the use of natural gas, crude oil and coal as a heating medium.

The limits of the use of the resources of restricted availability for the European Union in Poland are implemented by the regulations of the Ministry of Infrastructure concerning technical conditions referring to buildings and their locations. All the described documents influence on the scientific and technical breakthrough that takes place and concerns material and energy consumption in relation to economic efficiency and environmental responsibility. The year of 1990 for the mentioned documents and products is 'the technical reference point' and on the basis of international agreements up to 2020 the emission of greenhouse gas should be reduced by $20 \%$ and up to 2030 - by $30 \%$. It is planned to set the reduction concerning the emission of greenhouse gas on the level of $80 \%$ up to 2050 . The limitations referring to greenhouse gas emission have tightened the regulations in case of energy consumption, industry, transport and buildings. The changes concern the machines and devices as well as the materials used in architecture such as for example windows and doors $[8,31,32]$.

\section{Light partitions and glazing production in Poland and the dynamics of export development}

The experience of Polish producers in the production and export of light partitions and glazing has begun in 1990, when first production works using the technology of PVC profiles were brought to life. At the beginning the export from Poland was realized mostly to the countries of Middle Europe such as Slovakia, Czech Republic and Hungary. In the following years as the result of the possibility of getting international certificates allowing products for widespread circulation and use Polish producers started exporting the products also to countries such as Germany, France, Great Britain, Italy, Sweden and Belgium. In consequence of the adaptation of means of transport and products to the requirements of particular European countries the significant increase in the level of export in Poland has been observed except for the year of 2009. The implementation of such technical and commercial policy resulted in the highest export level of windows and doors in Polish production in 2015 in comparison with other European Union countries [7, 9, 23]. 
Table 1

Changes in export level of PVC light partitions and glazing from Poland within the years of 2007-2017 [Central Statistical Office data]

\begin{tabular}{|c|c|}
\hline Year & Yearly percentage change of export level \\
\hline 2007 & $38.1 \%$ \\
\hline 2008 & $22.4 \%$ \\
\hline 2009 & $-7.1 \%$ \\
\hline 2010 & $27.3 \%$ \\
\hline 2011 & $13.1 \%$ \\
\hline 2012 & $9.5 \%$ \\
\hline 2013 & $3.9 \%$ \\
\hline 2014 & $12.9 \%$ \\
\hline 2016 & $13.9 \%$ \\
\hline 2017 & $10.8 \%$ \\
\hline
\end{tabular}

The implementation of innovative technological changes in production and adaptation of the methods of transport directed towards meeting standards and guidelines from the European Union influenced in a significant degree on the expansion of export directions of light partitions and glazing (windows and doors) from Poland to other countries [7].

Table 2

The export level of light partitions and glazing from Poland to the $\mathrm{EU}$ countries in 2017 [Branch Analysis data]

\begin{tabular}{|c|c|c|}
\hline $\begin{array}{c}\text { Position of export level from } \\
\text { Poland to other EU countries }\end{array}$ & Country & Percentage share \\
\hline 1 & Germany & $32.3 \%$ \\
\hline 2 & Great Britain & $12 \%$ \\
\hline 3 & France & $10.5 \%$ \\
\hline 4 & Italy & $6.1 \%$ \\
\hline 5 & Belgium & $5.8 \%$ \\
\hline 6 & Czech Republic & $4.7 \%$ \\
\hline 7 & Slovakia & $4.1 \%$ \\
\hline 8 & Sweden & $3.2 \%$ \\
\hline
\end{tabular}

\section{Research description}

In order to carry out simulation research as a reference window the construction of the dimensions of $1230 \mathrm{~mm} \times 1480 \mathrm{~mm}$ was defined. Computations of the coefficients of 
thermal permeability of the reference windows were carried out according to the guidelines described in EN 14351-1 standards, attachment E, table E.1 i E.2 [16, 24].

In the window under investigation the simulated changes were of constructional character directed towards meeting technical requirement standards issued within the years from 2011 up to 2021. The most significant technical parameter in the construction under discussion was the coefficients of thermal permeability. The coefficient of thermal permeability $U_{w}$ indicate the quantity of heat that permeate through $1 \mathrm{~m}^{2}$ of flat partition (light partition or glazing - e.g. window) within 1 hour with air temperature difference at both sides of 1 Kelvin [19, 24, 25].

The results of simulation research were related to common methods of securing windows in transport and their arrangement. In the research the reference window was secured with the protruding foil and cardboard spacers or spacers made of foamed polyethylene. The secure system described here cause construction widening by $30 \mathrm{~mm}$. The reference windows are transported on pallets with the loading surface of $1 \mathrm{~m}$.

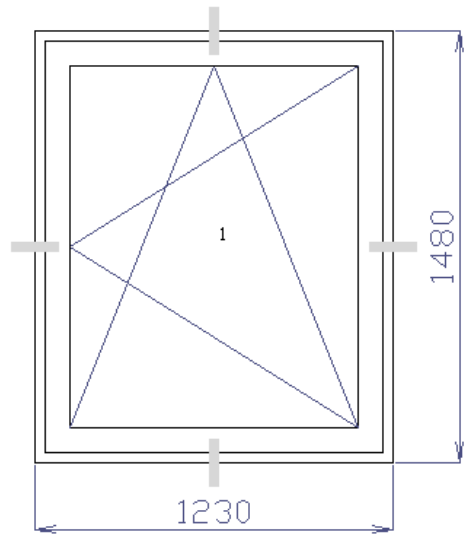

Fig. 1. Reference window according to the PN-EN 14351 standard

In order to obtain better thermal parameters of light partitions and glazing the producers modify mainly three elements constituting light partitions and glazing such as: glass, profiles and glass edge, according to the following mathematical formula [24]:

$$
\mathrm{U}_{w}=\frac{\sum A_{g} * U_{g}+\sum A_{f} * U_{f}+\sum I_{g} * \Psi_{g}}{\sum A_{g}+\sum A_{f}}
$$

where: $\mathbf{U}_{\mathbf{g}}$ - coefficient of glass thermal permeability, $\mathbf{A}_{\mathbf{g}}-$ glass area, $\mathbf{U}_{\mathbf{f}}-$ coefficient of profile thermal permeability, $\mathbf{A}_{\mathbf{f}}$ - Profile area, $\boldsymbol{\Psi}_{\mathbf{g}}$ - linear coefficient of thermal permeability caused by combined effect of glass, distance frame and profiles, $\mathbf{I}_{\mathbf{g}}-$ length of linear heating bridge between glass and frame. 
The investigation was carried out on the basis of PVC profile systems from such companies as Aluplast and Gealan. The two mentioned companies offer window-door technologies that are available within the whole area of the European Union. The investigation that was carried out concerned the development of PVC systems with respect to the changes of regulations that have taken place in Poland in the period of 2011-2021. The changes are presented in the tab. 3 [23].

Table 3

Required parameters of thermal permeability in the period of 2011-2021

\begin{tabular}{|c|c|}
\hline Duration in Poland & Parameter of window thermal permeability \\
\hline since 01.01.2021 & $0.9 \mathrm{~W} / \mathrm{m}^{2} \mathrm{~K}$ \\
\hline since 01.01.2017 till 31.12.2020 & $1.1 \mathrm{~W} / \mathrm{m}^{2} \mathrm{~K}$ \\
\hline since 01.01.2014 till 31.12.2016 & $1.3 \mathrm{~W} / \mathrm{m}^{2} \mathrm{~K}$ \\
\hline before 01.01.2014 & $1.5 \mathrm{~W} / \mathrm{m}^{2} \mathrm{~K}$ \\
\hline
\end{tabular}

\section{Description of simulation research carried out in the period of 2011-2013}

Up to 2013 the required parameter of thermal permeability in Poland was at the level of $1.5 \mathrm{~W} / \mathrm{m}^{2} \mathrm{~K}$. During his time Aluplast company designed the system called Ideal 2000 while Gealan company - S 3000 system. The construction of Ideal 2000 was of the width $76.5 \mathrm{~mm}$ while the construction of the Gealan system was of the width $79 \mathrm{~mm}$. Both variants for the reference window with one - chamber glass of thermal permeability of $1.0 \mathrm{~W} / \mathrm{m}^{2} \mathrm{~K}$ had thermal permeability for the whole window at the level of $1.4 \mathrm{~W} / \mathrm{m}^{2} \mathrm{~K}$ meeting At the same time technical and legal requirements presented in table $3[15,28]$.

According to the simulation that was carried out and the data under investigation concerning window supporting in transport on each pallet till the end of 20139 windows could be arranged. 


\section{Ideal 2000 \\ one-chamber glass}

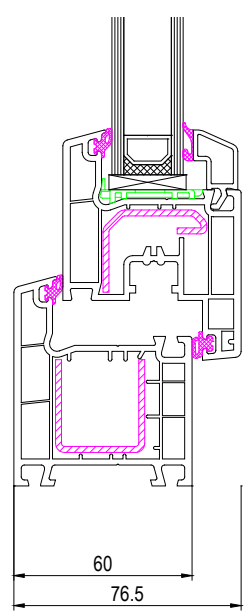

S 3000

one-chamber glass

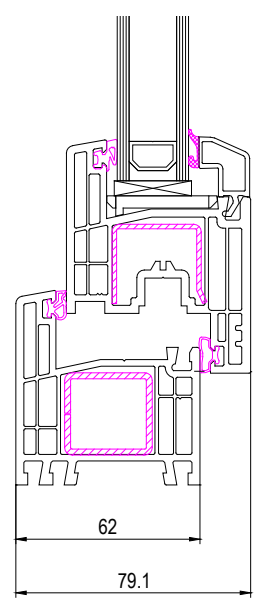

Fig. 2. Section of frame and sash profiles in Aluplast (Ideal 2000) and Gealan (S3000) systems [individual study supported by technical documentation]

\section{Description of simulation research carried out in the years 2014-2016}

The year of 2014 brought about tremendous changes both in case of values of thermal permeability coefficients and the increased demand for the surface of transported windows. The changes were caused by profile extension. The extension of profiles followed from the new requirements concerning thermal isolation that since 2014 were determined at the minimum value of $1.3 \mathrm{~W} / \mathrm{m}^{2} \mathrm{~K}$ [24].

At this time both companies discussed here designed and implemented new PVC systems. The Aluplast company introduced Ideal 4000 system, where the width of the frame of and sash together reached $89 \mathrm{~mm}$, while the Gealan company designed S7000 system, where the profile width was at the level of $90.5 \mathrm{~mm}$. The obtained values of the coefficient of thermal permeability for the reference window made in Ideal 4000 system were at the level of $1.3 \mathrm{~W} / \mathrm{m}^{2} \mathrm{~K}$ while the window made in $\mathrm{S} 7000$ system had the parameter of thermal permeability equal to $1.2 \mathrm{~W} / \mathrm{m}^{2} \mathrm{~K}$. In consequence of the technological changes on one pallet fewer windows - 8 items only - could be placed. Meeting legal requirements resulting from profile extension caused the increase of the demand for transport area by $11.11 \%$. It was the first break in window transport in the history of their manufacturing since 1997. The 
described break brought about the increased risk of domestic and international transport organization and concerned all producers of light partitions and glazing.

Ideal 4000

one-chamber glass

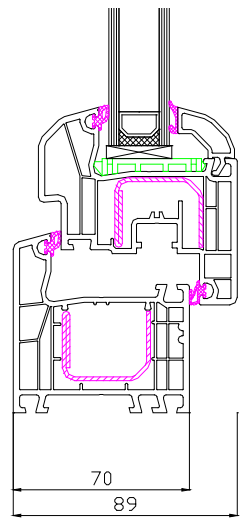

S7000

one-chamber glass

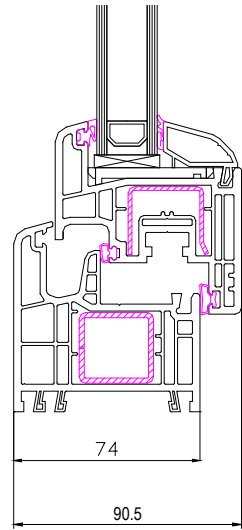

Fig. 3. Section of frame and sash profiles in Aluplast (Ideal 4000) and Gealan (S7000) systems [individual study supported by technical documentation]

\section{Description of simulation research carried out in the years 2017-2020}

According to table 3 in 2017 there was another change concerning required thermal properties of windows. Since January 2017 the windows installed in Poland should have the parameter of thermal isolation of $1.1 \mathrm{~W} / \mathrm{m}^{2} \mathrm{~K}$. As the value of the coefficient of thermal permeability follows from three components (thermal permeability of profiles, thermal permeability of glass and thermal permeability of the edges of glass), as it follows from the formula, the constructors of the PVC profile systems as well as glass producers sought for another way to realize the assumed purpose. They took advantage of the possibility of the application of glass of thermal permeability of $0.5 \mathrm{~W} / \mathrm{m}^{2} \mathrm{~K}$ in PVC profile systems previously used [4].

The exchange of one-chamber double glazing type of thermal permeability coefficient equal to $1.0 \mathrm{~W} / \mathrm{m}^{2} \mathrm{~K}$ for New two-chamber double glazing type with thermal permeability coefficient of $0.5 \mathrm{~W} / \mathrm{m}^{2} \mathrm{~K}$ fulfilled legal requirements with no necessity to implement new profile systems. According to the description, the change of glass had no impact on the change of flow of the windows being transported. Thermal permeability coefficient of the 
reference window produced in Ideal 4000 system with the thermal permeability coefficient of glass of $0.5 \mathrm{~W} / \mathrm{m}^{2} \mathrm{~K}$ according to the carried simulation research equals to $0.94 \mathrm{~W} / \mathrm{m}^{2} \mathrm{~K}$ while the one produced in S7000 system has the thermal permeability coefficient at the level of $0.96 \mathrm{~W} / \mathrm{m}^{2} \mathrm{~K}$. The exchange of glass types from one-chamber packets of the width $24 \mathrm{~mm}(4 / 16 / 4)$ into two-chamber packets of the width $44 \mathrm{~mm}(4 / 16 / 4 / 16 / 4)$ allowed for meeting all the legal requirements. Since 2017 on one pallet 8 items can be placed with no additional risk in transport organization.

Ideal 4000

two-chamber glass

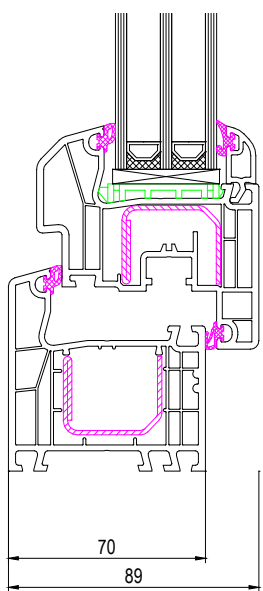

S7000

two-chamber glass

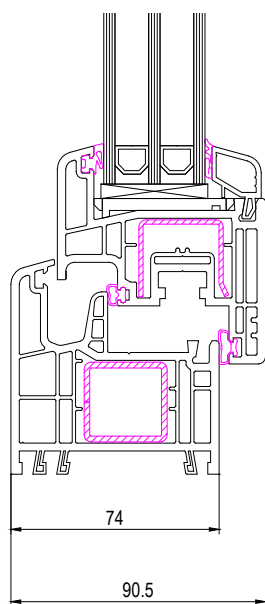

Fig. 4. Section of frame and sash profiles in Aluplast (Ideal 4000) and Gealan (S7000) systems with two-chamber glazing [individual study supported by technical documentation]

\section{Description of simulation research since 2021}

Meeting technical requirements that follow from the table 3 and are expected since 2021 is not possible on the way of technological changes of glass manufacturing. Since 2021 the described constructions are expected to have the minimum value of thermal permeability coefficient equal to $0.9 \mathrm{~W} / \mathrm{m}^{2} \mathrm{~K}$. In this situation both Aluplast and Gealan company designed new technological solutions that make possible to reach the demanded level of thermal permeability coefficient concerning light partitions and glazing. In response to the new technological requirements Aluplast company prepared Ideal 7000 system and Gealan company - S9000 profile system. The application of these new production technologies will allow for meeting legal requirements. The reference window with two- 
chamber glass with thermal permeability coefficient of $0.5 \mathrm{~W} / \mathrm{m}^{2} \mathrm{~K}$ produced in Ideal 7000 system will have thermal permeability at the level of $0.89 \mathrm{~W} / \mathrm{m}^{2} \mathrm{~K}$, while the one manufactured in S9000 system will have the thermal permeability coefficient equal to $0.9 \mathrm{~W} / \mathrm{m}^{2} \mathrm{~K}$. Anyway, it has to be emphasised that meeting legal requirements will result in another break in window transport, because the window produced in Ideal 7000 system will have the width of $109 \mathrm{~mm}$, while the one manufactured in $\mathrm{S} 9000$ system will be $101 \mathrm{~mm}$ wide. Due to technological changes in pallets discussed here there will be the possibility of the arrangement of 7 windows only on one pallet. The change of the possibility of the arrangement of the product will again cause the break of the possibility of transport (loading) space management by $12.5 \%$ and will be the consequence of the implemented technological change. The described break will increase the risk of domestic and international transport.

Ideal 7000 two-chamber glass

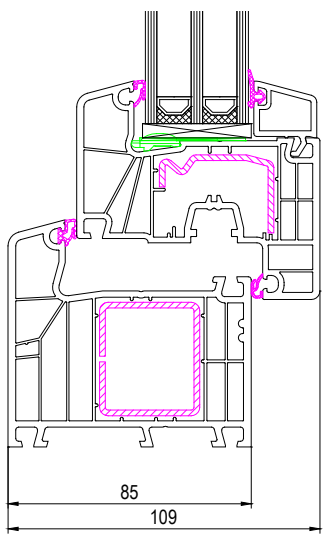

S9000

two-chamber glass

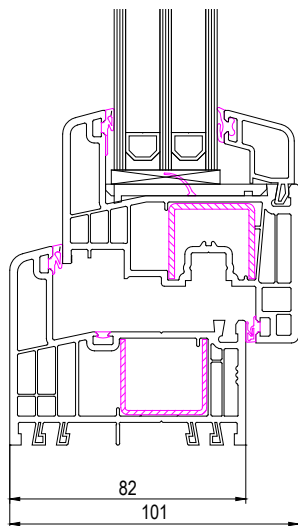

Fig. 5. Section of frame and sash profiles in Aluplast (Ideal 7000) and Gealan (S9000) systems with two-chamber glazing [individual study supported by technical documentation]

\section{Recapitulation}

From the data of the Centre of Branch Analyses it follows that in 2017730 producers exported in total 4,9 million items of windows and doors. Large and dynamically expanding scale of export for long distances should indicate the growing importance of technological development of such products as light partitions and glazing. According to the conducted research the year 2014 and 2021 are the breakthrough moments in window and door 
transport and the risk connected with the organization of international transport. From the statistics presented in tab. 3 and tab. 4 it follows that in case of both companies under investigation a significant drop (breakdown)of product transport possibilities occurred. The breakdown reached the level of $11,11 \%$ and was the consequence of the fact that on one pallet only 8 construction items could be placed. According to the conducted simulation research of thermal permeability coefficients and the impact of technological changes on the size of space needed for the construction being transported the Author predicts another breakdown in the field of transport in 2021 reaching the level of $12.5 \%$. This will be the consequence of the succeeding technological changes and another cut in the number of construction items arranged on one pallet down to 7 .

Table 4

The impact of technological changes of Aluplast company in the period of 2011-2021

\begin{tabular}{||c|c|c|c|c||}
\hline \hline $\begin{array}{c}\text { PVC profile system } \\
\text { from Aluplast company }\end{array}$ & $\begin{array}{c}\text { Ideal } 2000 \\
\text { (single } \\
\text { chamber glass) }\end{array}$ & $\begin{array}{c}\text { Ideal 4000 } \\
\text { (single } \\
\text { chamber glass) }\end{array}$ & $\begin{array}{c}\text { Ideal 4000 } \\
\text { (two chamber } \\
\text { glass) }\end{array}$ & $\begin{array}{c}\text { Ideal 7000 } \\
\text { (two chamber } \\
\text { glass) }\end{array}$ \\
\hline $\begin{array}{c}\text { Coefficient of thermal } \\
\text { permeability }\end{array}$ & $1.4 \mathrm{~W} / \mathrm{m}^{2} \mathrm{~K}$ & $1.3 \mathrm{~W} / \mathrm{m}^{2} \mathrm{~K}$ & $0.94 \mathrm{~W} / \mathrm{m}^{2} \mathrm{~K}$ & $0.89 \mathrm{~W} / \mathrm{m}^{2} \mathrm{~K}$ \\
\hline Construction width & $76.5 \mathrm{~mm}$ & $89 \mathrm{~mm}$ & $89 \mathrm{~mm}$ & $109 \mathrm{~mm}$ \\
\hline $\begin{array}{c}\text { Number of items } \\
\text { arranged on one pallet }\end{array}$ & 9 & 8 & 8 & 7 \\
\hline
\end{tabular}

Table 5

The impact of technological changes of Gealan company in the period of 2011-2021

\begin{tabular}{|c|c|c|c|c|}
\hline & $\mathbf{2 0 1 1 - 2 0 1 3}$ & $\mathbf{2 0 1 4 - 2 0 1 6}$ & $\mathbf{2 0 1 7 - 2 0 2 0}$ & $\mathbf{2 0 2 1}$ \\
\hline $\begin{array}{c}\text { PVC profile system } \\
\text { from Gealan company }\end{array}$ & $\begin{array}{c}\text { S } 3000 \\
\text { (single } \\
\text { chamber glass) }\end{array}$ & $\begin{array}{c}\text { S 7000 } \\
\text { (single } \\
\text { chamber glass) }\end{array}$ & $\begin{array}{c}\text { S 7000 } \\
\text { (two chamber } \\
\text { glass) }\end{array}$ & $\begin{array}{c}\text { S 9000 } \\
\text { (two chamber } \\
\text { glass) }\end{array}$ \\
\hline $\begin{array}{c}\text { Coefficient of thermal } \\
\text { permeability }\end{array}$ & $1.4 \mathrm{~W} / \mathrm{m}^{2} \mathrm{~K}$ & $1.2 \mathrm{~W} / \mathrm{m}^{2} \mathrm{~K}$ & $0.96 \mathrm{~W} / \mathrm{m}^{2} \mathrm{~K}$ & $0.9 \mathrm{~W} / \mathrm{m}^{2} \mathrm{~K}$ \\
\hline Construction width & $79.1 \mathrm{~mm}$ & $90.5 \mathrm{~mm}$ & $90.5 \mathrm{~mm}$ & $101 \mathrm{~mm}$ \\
\hline $\begin{array}{c}\text { Number of items } \\
\text { arranged on one pallet }\end{array}$ & 9 & 8 & 8 & 7 \\
\hline
\end{tabular}

The results of the conducted investigation suggest that the development of such products as light partitions and glazing should not engage profile width extension because the effectiveness of such solution will be limited by additional loss of transport efficiency. The requirements concerning the improvement of such technical conditions as the parameters of thermal permeability of windows in the described situations have a negative impact on the area occupied by the loading (windows). The increased demand for the transport area brings about the disruption in the balanced development taking into account the effective use of the available resources. The described disruption also causes the 
additional $\mathrm{CO}_{2}$ emission due to the need of the organization of additional transport. As the consequence of technological changes that will be applied in 2021 traffic congestions may occur caused by large number of cars transporting light partitions and glazing such as windows and doors [7, 15, 31].

Only complex technological solutions applied in the production of building materials taking into account also the aspects connected with transport may have a positive impact on the reduction of greenhouse gas emission. In order to improve thermal parameters of constructions with no loss of transport possibilities the Author suggests the development of alternative technologies for production of successively wider PVC profiles. The technologies that should have the priority in development are those that use foamed materials inside the chambers of the PVC profiles. Another possibility is to use modern composites or substitutes for such materials as areogels [1, 4, 20].

Another possibility to improve the parameters of thermal permeability is the implementation of innovative technologies of glue sticking profiles directly to glass and thus eliminating thermal bridges and steel inside. Another possibility that should be considered in the aspect of technological development of products and their protection in transport is the use of recycled material [20].

The technologies mentioned here are rarely analysed and applied in construction industry in European countries. It is the consequence of applicable requirements for thermal permeability. Table 6 presents the requirements concerning the coefficient of thermal permeability that apply in chosen countries [7].

Table 6

Comparative analysis of the required values of thermal permeability coefficients of light partitions and glazing applicable Since 2017 up to 2021 in chosen European countries [Centre of Branch Analysis data]

\begin{tabular}{|c|c|c|}
\hline Position & Country & $\begin{array}{c}\text { Value of thermal permeability } \\
\text { coefficient }\end{array}$ \\
\hline 1 & Poland since 2021 & $0.9 \mathrm{~W} / \mathrm{m}^{2} \mathrm{~K}$ \\
\hline 2 & Finland & $1.0 \mathrm{~W} / \mathrm{m}^{2} \mathrm{~K}$ \\
\hline 3 & Poland up to 2021 & $1.1 \mathrm{~W} / \mathrm{m}^{2} \mathrm{~K}$ \\
\hline 4 & Czech Republic, Norway & $1.2 \mathrm{~W} / \mathrm{m}^{2} \mathrm{~K}$ \\
\hline 5 & Germany & $1.3 \mathrm{~W} / \mathrm{m}^{2} \mathrm{~K}$ \\
\hline 6 & Austria & $1.4 \mathrm{~W} / \mathrm{m}^{2} \mathrm{~K}$ \\
\hline 7 & Denmark & $1.5 \mathrm{~W} / \mathrm{m}^{2} \mathrm{~K}$ \\
\hline
\end{tabular}

From the values presented in tab. 6 it follows that the requirements concerning light partitions and glazing since 2021 are going to be at the highest level in the European Countries. The experience and conclusions following from the adaptation of producers in Poland to such strict technical and legal standards may become a turning point for the development of products in other EU countries and the risk connected with the organization 
of international transport. It should be stressed that the totally balanced development of technology takes place only in case of complex activities that take into account both transport aspects and $\mathrm{CO}_{2}$ as well as other factors influencing so-called 'product life cycle'.

The presented research project has a significant impact on strategic European Union goals that are contained in such documents as 'Europe 2020', 'The White Book of Transport' and 'The Strategy of Transport Development up to 2020 (with the perspective to 2030$)^{\prime}$.

\section{References}

1. Brostow W., Osmanson T.: From mechanics to thermodynamics: A relation between the brittleness and the thermal expansivity for polymers. Mater. Lett. X 1, 100005, 2019.

2. Brostow W., Hagg Lobland H.E.: Materials: Introduction and Applications. 2017.

3. Brostow W., Hagg Lobland H.E., Narkis M.: Sliding wear, viscoelasticity and brittleness of polymers, Res. 21, 2006.

4. Brostow W., Hagg Lobland H.E.: Brittleness of materials: implications for composites and a relation to impact strength, J. Mater. Sci. 45, 2010.

5. Brostow W., Hagg Lobland H.E., Khoja S.: Brittleness and toughness of polymers and other materials. Mater. Lett. 159 478, 2015.

6. Bubień J.: Machinery for window production. Machinery for the production of PVC windows and doors. Window Quarterly; No. 1, 1990.

7. Center for industry analyzes $2017,2018$.

8. Czajka Z.: Changes resulting from new regulation on technical conditions to be met by buildings and their location, concerning windows, doors, gates and hardware. Window Quarterly No. 4, 2002.

9. Geryło R.: Thermal quality of windows in user's perspective. World of Glass, No. 1, 2007.

10. Gryc M., Gryc J.: Implementation of qualitative management in companies related to the improvement of effectiveness. Window Quarterly, No. 1, 2005.

11. ITB PVC Profile systems according to current Technical Approvals. Window Quarterly, No. 4, 2004.

12. Januła E., Truś T., Gutowska Z.: Spedycja. Wydawnictwo Difin, Warszawa 2011, p. $29-44$.

13. Januła E.: Podstawy transportu i spedycji. Wydawnictwo Difin, Warszawa 2014, p. $20-24$.

14. Jurkowski B., Rydarowski H.: Polymer materials with reduced flammabilty. Radom 2012.

15. Kacperczyk R., Środki transportu, cz. 2. Wydawnictwo Difin, Warszawa 2014, p. 281290. 
16. Karaś R., Michlowicz E.: Effect of thermal insulation PVC window profiles on environmental protection. Environmental protection issues; p. 155-164, 2006.

17. Kisielewicz T.: Thermal Characteristics of collector and accumulation partition. Window Quarterly, No. 2, 2003.

18. Kleiberg M.: Environmental effectiveness of technologies p. 18-23, 2011.

19. Kozłowski M., Macyszyn J., Karaś R.: Thermoplastic cellular composites. W: Biokompozyty z surowców odnawialnych, eds. S. Kuciel, H. Rydarowski, Politechnika Krakowska, Kraków 2012.

20. Kozłowski M. (red.), Plastic recycling in Europe. Wrocław 2006, p. 197-215.

21. Kozłowski M., Kozłowska A., Frąckowiak S.: Polymeric materials witch cellular structure. Polymers 10, 2010.

22. Kubik J., Maraczny K.: Multi-layer composites made of recycled plastic. 2001, p. 1118.

23. Łakota K.: Window profile ma in Poland. Window Quarterly, No. 4, 2005.

24. Lis P., Lis A.: Selected methods of limiting heat loss through windows. Window Quarterly, No. 1, 2003.

25. Macyszyn J., Karaś R., Kozłowski M.: Nowoczesne mateeriały termoizolacyjne o strukturze komórkowej [Modern insulating materials with cellular structure]. W: Współczesne metody i techniki w badaniach systemów inżynieryjnych, ed. S. Anisimov, Wrocław 2011.

26. Makarewicz M.: Replacement of external windows and doors. World of Glass 4, 2008.

27. Mieczkowski P.: Thermal insulation of glass partitions. Window Quarterly; No. 3, 2006.

28. Nantka M.: Selected results of thermal insulation and airtightness of windows. Window Quarterly, No. 3, 2000.

29. Płoński J.: Replacement of external windows and doors. World of Glass 11, 2006.

30. Prochowski L., Żuchowski A.: Technika transportu ładunków. Wyd. 2, Warszawa 2016, p. 39-46.

31. Rydzkowski W., Wojewódzka-Król K.: Transport. PWN, Warszawa 2010, s. 424-530.

32. Rydzykowski W. (ed.): Współczesna polityka transportowa [Contemporary Transport Policy]. PWE, Warszawa.

33. Stefańczyk B., Mieczkowski P.: Material conditions while using modern glass in construction industry and architecture. Window Quarterly, No. 2, 2005.

34. Wielgo M.: Market Research and Analysis Centre, 2016.

35. Windows and doors product standard, operating characteristics EN 14351, 2010. 